\title{
Ectoparasites community in Satanoperca jurupari (Cichlidae) from the Jari River, a tributary from Amazon River in Northern Brazil
}

\author{
Comunidade de ectoparasitos em Satanoperca jurupari (Cichlidae) do Rio Jari, um tributário do \\ Rio Amazonas no Norte do Brasil
}

Marcos Sidney Brito de Oliveira ${ }^{1}$; Raissa Alves Gonçalves²; Lígia Rigor Neves³; Drielly Oliveira Ferreira ${ }^{4}$; Marcos Tavares-Dias ${ }^{3,4 *}$

\author{
${ }^{1}$ Programa de Pós-graduação em Recursos Aquáticos e Continentais Amazônicos - RACAM, Universidade Federal do Oeste do \\ Pará - UFOPA, Santarém, PA, Brasil \\ ${ }^{2}$ Programa de Pós-graduação em Aquicultura, Universidade Nilton Lins, Manaus, AM, Brasil \\ ${ }_{3}^{3}$ Programa de Pós-graduação em Biodiversidade e Biotecnologia - PPGBIONORTE, Universidade Federal do Amapá - UNIFAP, \\ Macapá, AP, Brasil \\ ${ }^{4}$ Embrapa Amapá, Macapá, AP, Brasil
}

Received November 25, 2016

Accepted April 25, 2017

\begin{abstract}
The aim of this study was to investigate the gills parasites in Satanoperca jurupari from the Jari River, state of Amapá, in eastern Amazon (Brazil). The gills of $100 \%$ of the hosts were parasitized by Ichthyophthirius multifliiis (Protozoa), Sciadicleithrum juruparii (Monogenoidea) Genarchella genarchella, Posthodiplostomum sp. (Digenea) Ergasilus coatiarus and Argulus multicolor (Crustacea), and a total of 27,043 parasites were collected. However, the dominance was of I. multifliiis and there was aggregated dispersion of parasites with greater discrepancy for S. juruparii and A. multicolor. Low species richness of parasites $(3.1 \pm 1.1)$, low Brillouin diversity index $(0.27 \pm 0.23)$, low evenness $(0.16 \pm 0.13)$ and high dominance of Berger-Parker $(0.88 \pm 0.15)$ were found. The community of parasites in $S$. jurupari was characterized by low species richness, low diversity and low evenness, with high prevalence and low abundance. The size of host did not have any influence on the parasites community, but the host behavior and availability of infective stages of the parasites were factors structuring the community of ectoparasites found here.
\end{abstract}

Keywords: Aggregation, diversity, freshwater fish, parasites.

\section{Resumo}

O objetivo deste estudo foi investigar a comunidade de parasitos das brânquias de Satanoperca jurupari do Rio Jari, Estado do Amapá, região da Amazônia oriental (Brasil). As brânquias de 100\% dos hospedeiros estavam parasitadas por Ichthyophthirius multifliiis (Protozoa), Sciadicleithrum juruparii (Monogenoidea), Genarchella genarchella, Posthodiplostomum sp. (Digenea), Ergasilus coatiarus e Argulus multicolor (Crustacea) e foi coletado um total de 27.043 parasitos. Porém, a dominância foi de I. multifliiis e houve dispersão agregada de parasitos com maior discrepância de S. juruparii e $A$. multicolor . Foi encontrada uma baixa riqueza de espécies de parasitos $(3,1 \pm 1,1)$, baixa de diversidade de Brillouin $(0,27 \pm 0,23)$, baixa equitabilidade do índice de diversidade $(0,16 \pm 0,13)$ e elevada dominância de Berger-Parker $(0,88 \pm 0,15)$. A comunidade de parasitos foi caracterizada por baixa riqueza de espécies, baixa diversidade, baixa uniformidade, alta prevalência e baixa abundância. $\mathrm{O}$ tamanho dos hospedeiros náo teve influência sobre a comunidade parasitos, mas o comportamento dos hospedeiros e a disponibilidade de formas infectantes dos parasitos foram os fatores estruturando a comunidade dos ectoparasitos encontrados.

Palavras-chave: Agregação, diversidade, peixes de água doce, ectoparasitos.

\footnotetext{
*Corresponding author: Marcos Tavares-Dias. Embrapa Amapá, Rodovia Juscelino Kubitschek, Km 5, 2600, CEP 68903-419, Macapá, AP, Brasil. e-mail: marcos.tavares@embrapa.br
} 


\section{Introduction}

The Cichlidae represent one of the most species-rich and widespread families of fish distributed across the Americas, Africa, and Asia, with around 1700 valid species (VANHOVE et al., 2016), including Satanoperca jurupari Heckel, 1840, which is named as demon eartheater, eartheating devilfish or acará-bicudo. It has a wide distribution in the Amazon River system, ranging from Peru, Ecuador and Colombia to the mouth of the Amazon River in Brazil, in the state of Amapá and in eastern French Guyana, as well as in the Bolivian Amazon drainage, except for the Guaporé River (KULLANDER, 2003; FROESE \& PAULY, 2017). This cichlid is an ornamental fish that is also consumed by riverine human population, because they can reach $25 \mathrm{~cm}$ of total length. Satanoperca jurupari is benthopelagic and omnivorous fish, with a diet consisting of micro-crustaceans, fruit seeds, grasses and small fish, as well as aquatic and terrestrial insect larvae. The species has multiple spawns and takes parental care, putting the eggs and larvae into the oral-pharyngeal cavity. In addition, it does not perform schooling to reproduce (SANTOS et al., 2004; SOARES et al., 2011; QUEIROZ et al., 2013; FROESE \& PAULY, 2017; TAVARES-DIAS et al., 2017). Despite the importance of this fish for the Amazon region, little is known about its parasitic fauna.

Concerning the ectoparasite infracommunities of S. jurupari, Malta (1984) reported Argulus multicolor in hosts from the Janaucá Lake, in the Amazonas state. Yamada et al. (2009) described the monogenoidean Sciadicleithrum satanopercae Yamada, Takemoto, Bellay \& Pavanelli, 2009 of the Sciadicleithrum jurupari Melo, Santos \& Santos, 2012 gills from the Paraná River basin, in the state of Paraná. For this host from Gaumá River, in the state of Pará, nematode Pseudoproleptus sp. (MELO et al., 2011) and monogenoidean S. juruparii (MELO et al., 2012) were described. Protozoans Piscinoodinium pillulare Schäperclaus, 1954, Lom, 1981 and Ichthyophthirius multifiliis Fouquet, 1866; monogenoideans Sciadicleithum juruparii Yamada et al., 2009 and S. satanopercae; digeneans Posthodiplostomum sp., Clinostomum marginatum Rudolphi, 1819 and Genarchella genarchella Kohn \& Fernandes,1988; acantocephalans Gorytocephalus spectabilis Machado- from the Igarapé Fortaleza basin, in eastern Amazon were reported (BITTENCOURT et al., 2014; TAVARES-DIAS et al., 2017). Recently, Paschoal et al. (2016) described the monogenoidean Sciadicleithrum edgari Paschoal, Scholz, Tavares-Dias \& Luque, 2016 from gills of this cichlid from the Araguari River, in state of Amapá (Brazil). However, there are few studies on the ectoparasites community and host-parasite interactions for wild $S$. jurupari populations. However, some ectoparasites interact with their fish hosts and this may have a profound impact on their health when in high abundance of infection.

Among the ecological traits of the hosts, size, age, diet, trophic level, life style, body condition, schooling behavior, population size and density, and geographical distribution range have been recognized as factors influencing richness and diversity of the parasite communities in fish population (POULIN \& FITZGERALD, 1987; ROHDE et al., 1995; MARQUES \& CABRAL, 2007; LONGSHAW et al., 2010; SILVA et al., 2011; ACOSTA et al.,
2013; COSTA-PEREIRA et al., 2014; OLIVEIRA et al., 2016). Water quality, habitat, season, temperature, geographic range, dissolved oxygen levels, etc., are among environmental factors that have been considered as key determinants that influence the richness and diversity of the parasite communities in fish populations (MORAND et al., 2002; LONGSHAW et al., 2010; SILVA et al., 2011, ACOSTA et al., 2013; BITTENCOURT et al., 2014; COSTA-PEREIRA et al., 2014). Therefore, the interaction between hosts and ectoparasites in fish populations is highly complex, and dynamic ecological systems resulting from these interactions of multiple factors may act together or not. Consequently, hosts or ectoparasites can be favored, depending on a number of factors. The aim of this study was to investigate the component community of ectoparasites in $S$. jurupari from the Jari River, an important tributary from lower Amazon River, in the eastern Amazon region (northern Brazil).

\section{Material and Methods}

\section{Study area}

The Jari River basin $\left(02^{\circ} 39^{\prime} 02^{\prime \prime} \mathrm{N}, 01^{\circ} 26^{\prime} 24^{\prime \prime} \mathrm{S}, 51^{\circ} 47^{\prime} 24^{\prime \prime} \mathrm{W}\right.$, $55^{\circ} 07^{\prime} 48^{\prime \prime} \mathrm{W}$ ) is an important tributary of the Amazon River in eastern Amazon (Figure 1), and it is spread over several municipalities from the states of Pará and Amapá, in northern Brazil. This river of clear water and low amount of suspended matter has its source in the Tumucumaque Mountain Park, located at the border between Brazil and Suriname (EPE, 2011). The Jari River basin is located in the state of Amapá, in eastern Amazon (Brazil), and it is characterized by having extensive river-floodplain system, high rainfalls and tides from the Amazonas River. Regional vegetation consists of plants characteristic of floodplain forests and periodically flooded herbaceous fields, composed mainly of various macrophytes species.

\section{Fish and parasite sampling}

In January 2014, 30 specimens of $S$. jurupari $(14.5 \pm 1.0 \mathrm{~cm}$ and $108.7 \pm 22.9 \mathrm{~g}$ ) were collected in the community area of Jarilândia, in the municipality of Vitória do Jari, state of Amapá, Brazil (Figure 1), for parasitological analysis. All fish were collected with nets of different meshes $(10-40 \mathrm{~mm})$ and cast nets. The gills, nostrils and mouth cavity of the fish were examined to ascertain whether any protozoan and metazoan parasites were present. Methodological techniques previously described were used to collect, fix, conserve, count and stain the ectoparasites for identification (EIRAS et al., 2006). To analyze the ectoparasite infracommunities, ecological terms used were those recommended by Bush et al. (1997). This study was developed in accordance with the principles adopted by the Brazilian College of Animal Experimentation (COBEA) and with authorization from the Ethics Committee in the Use of Animals of Embrapa Amapá (\# 004 - CEUA/CPAFAP).

The following descriptors for the parasites community were calculated: the species richness, Brillouin diversity index $(H B)$, evenness $(E)$ in association with diversity index, Berger-Parker 


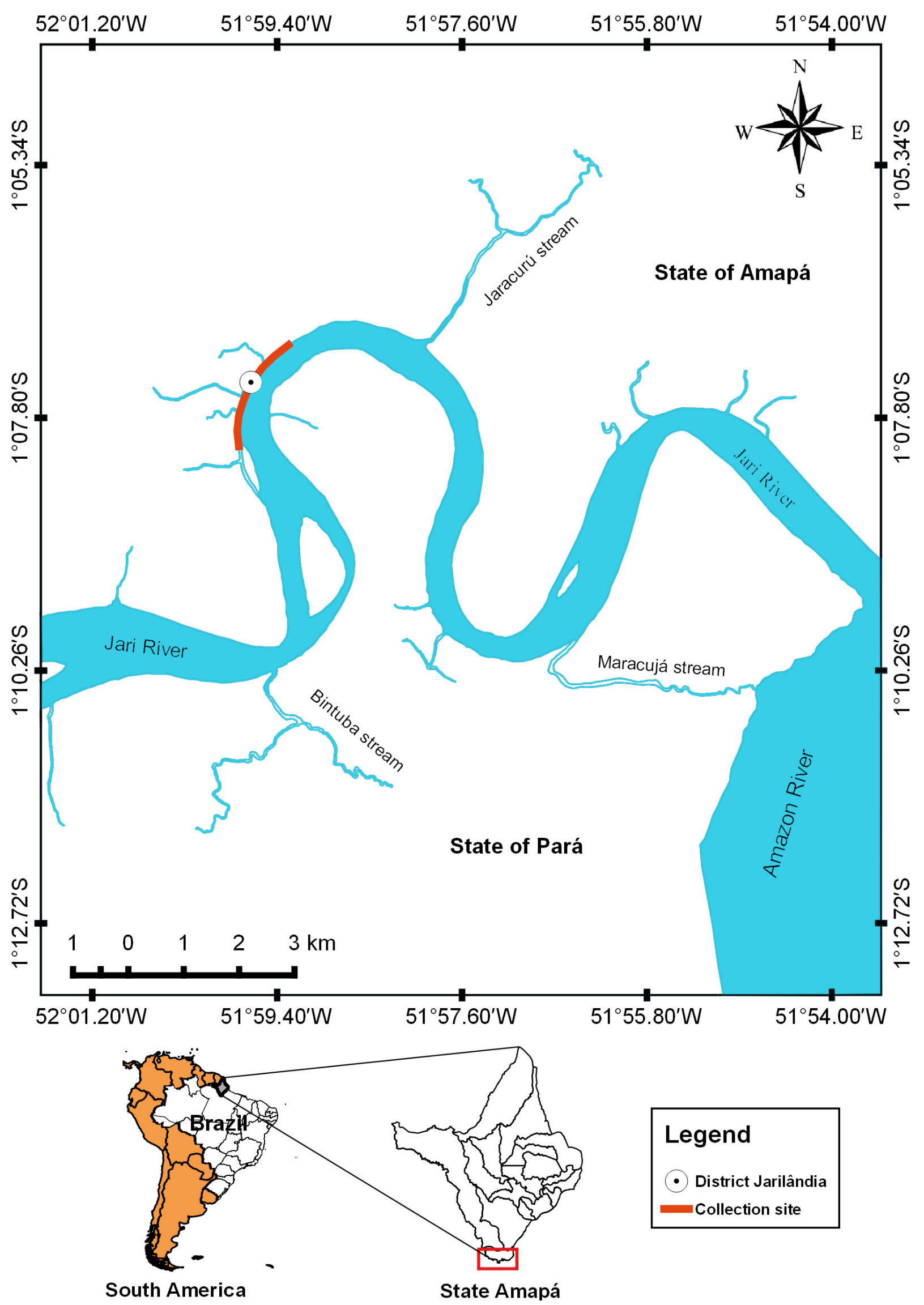

Figure 1. Collection locality of Satanoperca jurupari from Jari River, tributary from Amazon River in northern Brazil. 
Table 1. Ectoparasites in Satanoperca jurupari gills $(\mathrm{n}=30)$ from Jari River, tributary from Amazon River in northern Brazil.

\begin{tabular}{|c|c|c|c|c|c|c|}
\hline Parasites & $\mathbf{P}(\%)$ & MI & MA & Range & TNP & FD (\%) \\
\hline Ichthyophthirius multifiliis & 76.7 & $730.0 \pm 460.1$ & $559.6 \pm 569.9$ & $0-2088$ & 16.789 & 0.6208 \\
\hline Sciadicleithrum juruparii & 36.7 & $3.18 \pm 7.6$ & $1.2 \pm 2.7$ & $0-14$ & 35 & 0.0013 \\
\hline Genarchella genarchella (metacercariae) & 66.7 & $1.0 \pm 1.2$ & $0.7 \pm 1.0$ & $0-5$ & 20 & 0.0007 \\
\hline Posthodiplostomum sp. (metacercariae) & 86.7 & $390.7 \pm 945.5$ & $338.6 \pm 876.4$ & $0-3969$ & 10,157 & 0.3756 \\
\hline Argulus multicolor & 23.3 & $1.57 \pm 0.8$ & $0.4 \pm 0.8$ & $0-3$ & 11 & 0.0004 \\
\hline Ergasilus coatiarus & 43.3 & $2.38 \pm 1.3$ & $1.0 \pm 1.5$ & $0-5$ & 31 & 0.0011 \\
\hline
\end{tabular}

P: Prevalence; MI: Mean intensity; MA: Mean abundance and TNP: Total number of parasites; FD: Frequency of dominance.

dominance index $(d)$, and dominance frequency (percentage of the infracommunities in which a parasite species is numerically dominant (ROHDE et al., 1995; MAGURRAN, 2004), using the Diversity software (Pisces Conservation Ltd., UK). The index of dispersion (ID), and the index of discrepancy of Poulin (D) were calculated using the Quantitative Parasitology 3.0 software to detect the distribution pattern of parasite infracommunity (RÓZSA et al., 2000) for species with prevalence $>10 \%$. The ID significance for each infracommunity was tested using the $d$-statistics (LUDWIG \& REYNOLDS, 1988).

All fish were weighed $(\mathrm{g})$ and measured for total length $(\mathrm{cm})$. The body weight $(\mathrm{g})$ and standard length $(\mathrm{cm})$ of the fish were used to calculate the relative condition factor $(\mathrm{Kn})$ of hosts, which was compared to standard value $(\mathrm{Kn}=1.00)$ using the $t$-test $(U)$. Data of body weight $(\mathrm{Wt})$ and total length $(\mathrm{Lt})$ were also used to calculate the relative condition factor $(\mathrm{Kn})$ of fish using the length-weight relationship $\left(\mathrm{W}=\mathrm{aL}^{\mathrm{b}}\right)$ after logarithmic transformation of standard length and weight and subsequent adjustment of two straight lines, obtaining lny $=\ln A+B \ln x$ (LE CREN, 1951). The Spearman correlation coefficient $(r s)$ was used to determine possible correlations of parasites abundance with the length and weight, as well as with the parasite species richness and the Brillouin diversity index of the hosts (ZAR, 2010).

A principal component analysis (PCA) was carried out to investigate if body parameters and diversity indices have been influenced by the ectoparasites community. This multivariate analysis was performed using the Past-Paleontological Statistics software, version 3.0.

\section{Results}

The gills of all the examined fish were parasitized and 27.043 parasites, such as Ichthyophthirius multifliis (Cilliophora), Sciadicleithrum juruparii (Monogenoidea), metacercariae and adults of Genarchella genarchella; Posthodiplostomum sp. (Diplostomidae), Ergasilus coatiarus (Copepoda) and Argulus multicolor (Branchiura), were collected. There is a dominance of I. multifiliis (Table 1) and aggregated dispersion of parasites, with higher discrepancy for S. juruparii and A. multicolor (Table 2).

It was found a low species richness of parasites, low Brillouin diversity and low Evenness for S. juruparii (Table 3). Host length has shown no correlation with the species richness $(r s=0.048$, $\mathrm{p}=0.801)$ of ectoparasites and with the Brillion diversity index $(r s=0.034, \mathrm{p}=0.857)$. There was a predominance of hosts infected by 2 to 4 ectoparasite species (Figure 2).
Table 2. Index of dispersion (ID), $d$-statistic ( $d$ ) and discrepancy index (D) for the ectoparasites infracommunities of Satanoperca jurupari gills $(\mathrm{n}=30)$ from Jari River, tributary from Amazon River in northern Brazil.

\begin{tabular}{lccc}
\hline \multicolumn{1}{c}{ Species parasites } & ID & $\boldsymbol{d}$ & D \\
\hline Ichthyophthirius multifiliis & 2.556 & 4.682 & 0.408 \\
Sciadicleithrum juruparii & 2.241 & 3.917 & 0.721 \\
Posthodiplostomum sp. & 3.049 & 5.815 & 0.408 \\
Genarchella genarchella & 1.577 & 2.080 & 0.688 \\
Argulus multicolor & 1.596 & 2.138 & 0.795 \\
Ergasilus coatiarus & 2.101 & 3.559 & 0.671 \\
\hline
\end{tabular}

Table 3. Descriptors of diversity for ectoparasites community of Satanoperca jurupari gills $(\mathrm{n}=30)$ from Jari River, tributary from Amazon River in northern Brazil.

\begin{tabular}{lc}
\hline \multicolumn{1}{c}{ Diversity indices } & Mean \pm SD (Range) \\
\hline Species richness & $3.1 \pm 1.1(1-6)$ \\
Brillouin $(H B)$ & $0.27 \pm 0.23(0-0.78)$ \\
Evenness $(E)$ & $0.16 \pm 0.13(0-0.51)$ \\
Index of Berger-Parker $(d)$ & $0.88 \pm 0.15(0.49-1.00)$ \\
\hline
\end{tabular}

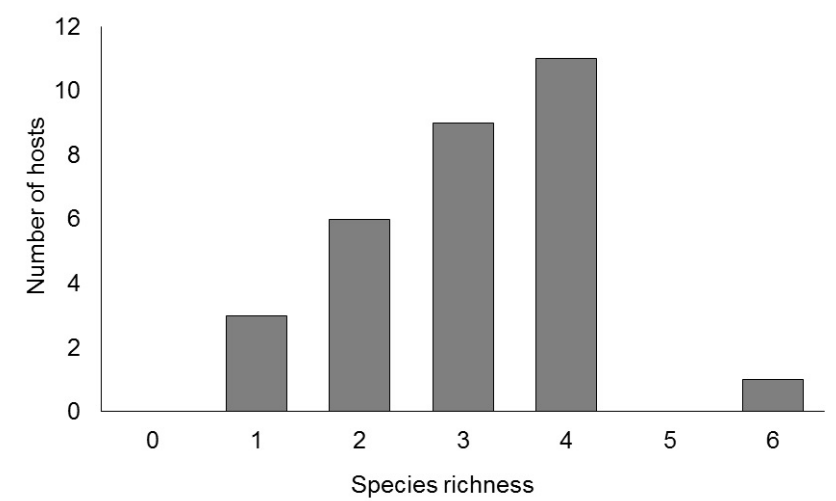

Figure 2. Species richness of ectoparasites in Satanoperca jurupari from Jari River, tributary from Amazon River in Northern Brazil.

Host's length shown no correlation with the abundance of I. multifiliis ( $r s=0.004, \mathrm{p}=0.983), S$. juruparii $(r s=0.066$, $\mathrm{p}=0.731)$, G. genarchella $(r s=-0.269, \mathrm{p}=0.150)$, Posthodiplostomum sp. $(r s=0.118, \mathrm{p}=0.535)$, E. coatiarus $(r s=0.089, \mathrm{p}=0.638)$ and A. multicolor $(r s=0.206, \mathrm{p}=0.274)$. Host weight does not also show any correlation with the abundance of $I$. multifliis $(r s=0.030, \mathrm{p}=0.875), S$. juruparii $(r s=0.074, \mathrm{p}=0.996)$, 


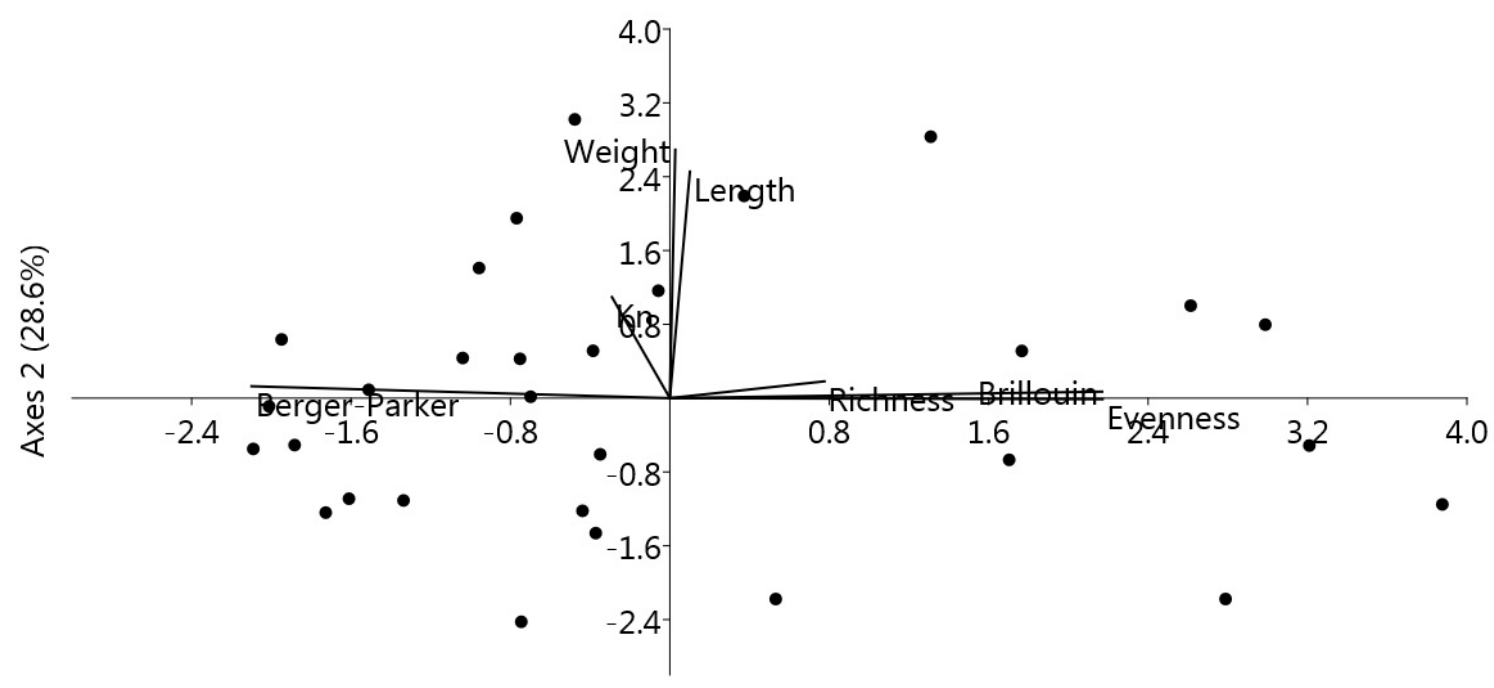

Axes $1(43.1 \%)$

Figure 3. Scatterplot scores of the principal component analysis (PCA) of factors influencing the ectoparasites communities in Satanoperca jurupari from the Jari River basin, tributary from Amazon River in northern Brazil. The values shown on the ordinate and abscissa axes represent the greatest quantity and variation of the data set. Kn: relative condition factor, Richness: Species richness.

G. genarchella ( $r s=-0.323, \mathrm{p}=0.082)$, Posthodiplostomum sp. $(r s=0.231, \mathrm{p}=0.219)$, E. coatiarus $(r s=0.173, \mathrm{p}=0.359)$ and A. multicolor ( $r s=0.100, \mathrm{p}=0.599)$. The Kn of the host has shown no correlation with the abundance of $I$. multifiliis ( $r s=0.083$, $\mathrm{p}=0.661), S$. juruparii $(r s=0.008, \mathrm{p}=0.968), G$. genarchella (rs $=-0.220, \mathrm{p}=0.242)$, E. coatiarus $(r s=0.314, \mathrm{p}=0.091)$ and $A$. multicolor $(r s=-0.0180, \mathrm{p}=0.342)$, but, on the other hand, it has shown a weak correlation with the abundance of Posthodiplostomum sp. ( $r s=0.420, \mathrm{p}=0.021)$.

The multivariate analysis of PCA based on the body and diversity parameters showed that the joint representation of the two main factors account for approximately $72 \%$ of the variance. The results allowed observing that the species richness, the Brillouin diversity index and the Berger-Parker index are the main factors related to the presence of parasites in hosts while the weight and length of the hosts had no relationship with the parasites (Figure 3).

The equation of weight (W)-length (L) relationship for this host was $\mathrm{W}=0.0732 \mathrm{~L}^{2.7244}, \mathrm{r}^{2}=0.875$ ), with negative allometric, indicating greater increase in body weight than in size. The Kn $(1.00 \pm 0.01)$ of hosts was not different $(t=-0.002, p=0.99)$ from the pattern $\mathrm{Kn}(\mathrm{Kn}=1.00)$, indicating good body conditions.

\section{Discussion}

Due to increased interest in wild fish population for aquaculture, there has been an increased interest in parasites of fishes and the diseases associated with them. Therefore, any attempt to increase the productivity in fish farms or to improve the stocks of valuable commercial fisheries in the natural waters, requires detailed knowledge on the parasites inhabiting the localities involved and infects the fish populations.
The community of ectoparasites in S. jurupari from the Jari River consisted of two species of crustaceans, two digeneans, one protozoan and one monogenoidean. However, I. multifliiis was the dominant species in this study, and most ectoparasite species had a high prevalence and low abundance of infection. Similar community of ectoparasites was reported for this native cichlid species from the Igarapé Fortaleza River (TAVARES-DIAS et al., 2017). The interaction between biotic and abiotic factors is essential for the composition and structure of parasite communities (MORAND et al., 2002; SILVA et al., 2011; ACOSTA et al., 2013; COSTA-PEREIRA et al., 2014; OLIVEIRA et al., 2016; TAVARES-DIAS et al., 2017). Therefore, due to the complex parasite-host-environment interaction, initially, the parasites attempt to establish themselves in the host while the host resists the infection via its immune defense mechanisms (SILVA et al., 2011; ROHLENOVÁ et al., 2011). Consequently, host susceptibility and resistance will determine whether the infection becomes established in wild host populations.

In this study, we found an overdispersion of ectoparasites in S. jurupari. Possible causes for this type of parasite distribution pattern on fish are common to many ectoparasites (ACOSTA et al., 2013; COSTA-PEREIRA et al., 2014; TAVARES-DIAS et al., 2015; OLIVEIRA et al., 2016; TAVARES-DIAS et al., 2017). Such causes include differences among host individuals regarding susceptibility to parasites, possible tendencies for fish that have acquired one parasite to acquire others, and different probabilities of encountering an infective stage of the ectoparasites in the environment (POULIN \& FITZGERALD, 1987; COSTA-PEREIRA et al., 2014; TAVARES-DIAS et al., 2015; OLIVEIRA et al., 2016). In addition, the coexistence of ectoparasites is favored by this intraspecific aggregation, once this type of dispersion distribution 
facilitates ectoparasites species coexistence in the host fish (MORAND et al., 2002).

Parasitic helminths, crustaceans and protozoans can be bioindicators (VIDAL-MARTÍNEZ et al., 2010; ACOSTA et al., 2013; OLIVEIRA et al., 2016). We found that in S. jurupari, the infection levels by $I$. multifliis and $S$. juruparii were higher than those reported for this cichlid species also from the Igarapé Fortaleza River, which was infected by I. multifiliis, P. pillulare and $S$. satanoperca (BITTENCOURT et al., 2014; TAVARESDIAS et al., 2017). Such differences for the same host species from different localities may be attributed to environmental characteristics and opportunity of these host fish to find infective stages of these ectoparasites. For protozoans and monogenoideans, some characteristics may facilitate the transmission and their establishment in fish; e.g., environmental conditions and sedentary behavior of $S$. jurupari. Such ectoparasites with a direct life cycle are more easily found in lentic environments, since it is less difficult for their infective forms to reach the hosts in this type of environment (DOGEL et al., 1961; SILVA et al., 2011; ACOSTA et al., 2013; BITTENCOURT et al., 2014; OLIVEIRA et al., 2016). Moreover, both ectoparasites taxa are also known to proliferate in eutrophic environments (VIDAL-MARTÍNEZ et al., 2010; SILVA et al., 2011; ACOSTA et al., 2013; BITTENCOURT et al., 2014; OLIVEIRA et al., 2016), which enables more exchange of parasites among the hosts.

Satanoperca jurupari is a benthopelagic fish, typical of quiet waters, which prefers environments with low depth to dig into the muddy substrate looking for food. This fish eats fruit seeds, crustaceans, grasses and small fish, as well as aquatic and terrestrial insect larvae and insects (SANTOS et al., 2004; SOARES et al., 2011; QUEIROZ et al., 2013; FROESE \& PAULY, 2017; TAVARES-DIAS et al., 2017) when it interacts with metacercariae of digeneans. Hosts of this study had a higher abundance of infection by Posthodiplostomum sp. than by G. genarchella. Both helminths are generalist parasites, thus they had been also reported to infect other different freshwater fishes from Brazil (KOHN et al., 2007; BITTENCOURT et al., 2014; TAVARES-DIAS et al., 2017). The transmission of digenean parasites, in general, is related to the living mode of the hosts, and these parasites of complex life cycle have primarily a mollusk species as an intermediate host, and subsequently a fish species that eats mollusks. However, many metacercariae species enter the host fish by active invasion of the cercariae, a generally planktonic larva that may accumulate into dense clouds in an aquatic environment, and its successful transmission depends on the behavior of the cercariae, as well as on the behavior of the host fish (MORLEY, 2012).

In $S$. jurupari of this study, A. multicolor and E. coatiarus were found in low abundance of infection. Sometimes, the interrelationship between hosts and crustacean parasites can lead to some associations resulting in host specificity and latitudinal gradients. Thus, some crustacean species prefer hosts from specific habitats or with particular behavior, besides specific-site on hosts, while most are opportunistic parasites. Moreover, some parasitic crustaceans can have wide distribution and other have endemic pattern (AVENANT-OLDEWAGE \& OLDEWAGE, 1993; TAVARES-DIAS et al., 2015). Among the species of Argulidae from Brazil, $A$. multicolor has mainly infested species of Cichlidae,
Serrasalmidae, Characidae and Pimelodidae; hence, it is widely distributed in the systems of the Amazon River and the Paraná River. However, E. coatiarus have only infested some cichlid species (TAVARES-DIAS et al., 2015; TAVARES-DIAS et al., 2017). Therefore, this species of argulids has no parasitic specificity.

In $S$. jurupari, the host size does not influence the ecological and community descriptors, due to the low range of length $(12.2-16.3 \mathrm{~cm})$ and the low abundance in most of the ectoparasites infracommunities. However, the lack of correlation of the host body size with the abundance of the ectoparasites can be due to the body mass that does not have any fundamental influence on the ectoparasite infracommunities found here. Indeed, multivariate analysis based on body parameters and diversity parameters showed that only the species richness, the Brillouin diversity and the Berger-Parker index were the main factors in vectorial importance order. Although the host body size is widely used to determine correlations between parasitic ecological and community descriptors, due to correlations found (negative or positive), there is not a consensus on this issue (SILVA et al., 2011; COSTA-PEREIRA et al., 2014; OLIVEIRA et al., 2016; TAVARES-DIAS et al., 2017).

Finally, the ectoparasite community in $S$. jurupari presented low species richness, low diversity and low evenness, and it consists of species with high prevalence and low abundance, which does not affect hosts' body condition. The size of host did not have any influence on the ectoparasite communities; however, the host behavior and availability of infective stages of the parasites were factors structuring the communities of ectoparasites found in this host.

\section{Acknowledgements}

M. Tavares-Dias was granted Research Fellowship (\# 303013/2015-0) from the National Counsel of Technological and Scientific Development (CNPq, Brazil). L.R Neves and M.S.B. Oliveira were granted a bursary from the Coordination for the Improvement of Higher Education Personnel (Capes, Brazil).

\section{References}

Acosta AA, Queiroz J, Brandão H, Carvalho ED, Silva RJ. Helminths of Steindachnerina insculpta in two distinct stretches of the Taquari River, state of São Paulo, Brazil. Rev Bras Parasitol Vet 2013; 22(4): 539-547. PMid:24473879. http://dx.doi.org/10.1590/S1984-29612013000400014.

Avenant-Oldewage A, Oldewage WH. The occurrence of fish parasites in the Kwando River, Caprivi, Namibia. Madoqua 1993; 18(2): 183-185.

Bittencourt LS, Pinheiro DA, Cárdenas MQ, Fernandes BMM, TavaresDias M. Parasites of native Cichlidae populations and invasive Oreochromis niloticus (Linnaeus, 1758) in tributary of Amazonas River (Brazil). Rev Bras Parasitol Vet 2014; 23(1): 44-54.

Bush AO, Lafferty KD, Lotz JM, Shostak AW. Parasitology meets ecology on its own terms: Margolis et al. revisited. J Parasitol 1997; 83(4): 575583. PMid:9267395. http://dx.doi.org/10.2307/3284227.

Costa-Pereira R, Paiva F, Tavares LER. Variation in the parasite community of the sardine fish Triportheus nematurus (Actinopterygii: Characidae) 
from the Medalha lagoon in the Pantanal wetland, Brazil. J Helminthol 2014; 88(3): 272-277. PMid:23506711. http://dx.doi.org/10.1017/ S0022149X1300014X.

Dogel VA, Petrushevski GK, Polyanski YI. Ecology of the parasites of freshwater fishes. In: Dogel VA, Petrushevski GK, Polyanski YI. Parasitology of fishes. Leningrad: University Press; 1961. p. 1-47.

Eiras JC, Takemoto RM, Pavanelli GC. Métodos de estudo e técnicas laboratoriais em parasitologia de peixes. Maringá: Eduem; 2006.

Empresa de Pesquisa Energética - EPE. Estudo de inventário hidrelétrico: relatório final: avaliação ambiental integrada. Rio de Janeiro: EPE; 2011.

Froese R, Pauly D, editors. FishBase: version 02/2017 [online]. 2017 [cited 2017 March 15]. Available from: www.fishbase.org

Kohn A, Fernandes BMM, Cohen SC. South American trematodes parasites of fishes. Rio de Janeiro: Imprinta Express; 2007.

Kullander SO. Family Cichlidae (cichlids). In: Reis RE, Kullander SO, Ferraris C Jr. Check List of the freshwater fishes of South and Central America. Porto Alegre: Edipucrs; 2003. p. 605-654.

Le Cren ED. The length-weight relationship and seasonal cycle in gonad weight and condition in the perch (Perca fluviatilis). J Anim Ecol 1951; 20(2): 201-219. http://dx.doi.org/10.2307/1540.

Longshaw M, Frear PA, Nunn AD, Cowx IG, Feist SW. The influence of parasitism on fish population success. Fish Manag Ecol 2010; 17(5): 426-434. http://dx.doi.org/10.1111/j.1365-2400.2010.00741.x.

Ludwig JA, Reynolds JF. Statistical Ecology: a primer on methods and computing. New York: Wiley-Interscience Pub; 1988.

Magurran AE. Measuring biological diversity. Oxford: Blackwell Science; 2004.

Malta JCO. Os peixes de um lago de várzea da Amazônia Central (Lago Janauacá, Rio Solimôes) e suas relaçôes com os crustáceos ectoparasitas (Branchiura: Argulidae). Acta Amaz 1984; 14(3-4): 355-372. http:// dx.doi.org/10.1590/1809-43921984143372.

Marques JF, Cabral HN. Effects of sample size on fish parasite prevalence, mean abundance and mean intensity estimates. J Appl Ichthyology 2007; 23(2): 158-162. http://dx.doi.org/10.1111/j.1439-0426.2006.00823.x.

Melo MF, Giese EG, Santos JN, Portes Santos C. First record of Pseudoproleptus sp. (Nematoda: Cystidicolidae) in fish host. Acta Trop 2011; 117(3): 212-215. PMid:21187054. http://dx.doi.org/10.1016/j. actatropica.2010.12.011.

Melo MF, Santos JN, Santos CP. Sciadicleithrum juruparii n. sp. (Monogenea: Ancyrocephalidae) from the gills of Satanoperca jurupari (Heckel) (Osteichthyes: Cichlidae) in the Guamá River, Amazon Delta, Brazil. Syst Parasitol 2012; 82(2): 125-129. PMid:22581249. http:// dx.doi.org/10.1007/s11230-012-9353-z.

Morand S, Rohde K, Hayward C. Order in ectoparasite communities of marine fish is explained by epidemiological processes. Parasitology 2002;124(7 Suppl): S57-S63. PMid:12396216. http://dx.doi.org/10.1017/ S0031182002001464.

Morley NJ. Cercariae (Platyhelmintes: Trematoda) as neglected components of zooplankton communities in freshwater habitats. Hydrobiologia 2012; 691(1): 7-19. http://dx.doi.org/10.1007/s10750-012-1029-9.

Oliveira MSB, Gonçalves RA, Tavares-Dias M. Community of parasites in Triportheus curtus and Triportheus angulatus (Characidae) from a tributary of the Amazon River system (Brazil). Stud Neotrop Fauna Environ 2016; 51(1): 29-36. http://dx.doi.org/10.1080/01650521.2016.1150095.

Paschoal F, Scholz T, Tavares-Dias M, Luque JL. Dactylogyrids (Monogenea) parasitic on cichlids from northern Brazil, with description of two new species of Sciadicleithrum and new host and geographical records. Acta Parasitol 2016; 61(1): 158-164. PMid:26751887. http://dx.doi. org/10.1515/ap-2016-0021.

Poulin R, Fitzgerald GJ. The potential of parasitism in the structuring of a salt marsh stickleback community. Can J Zool 1987; 65(11): 2793 2798. http://dx.doi.org/10.1139/z87-421.

Queiroz LJ, Torrente-Vilara G, Hoara WM, Pires THS, Zuanon J, Doria CRC. Peixes do Rio Madeira. 3. ed. São Paulo: Dialeto Latin American Documentary; 2013.

Rohde K, Hayward C, Heap M. Aspects of the ecology of metazoan ectoparasites of marine fishes. Int J Parasitol 1995; 25(8): 945-970. PMid:8550295. http://dx.doi.org/10.1016/0020-7519(95)00015-T.

Rohlenová K, Morand S, Hyršl P, Tolarová S, Flajšhans M, Šimková A. Are fish immune systems really affected by parasites? An immunoecological study of common carp (Cyprinus carpio). Parasit Vectors 2011; 4(1): 120. PMid:21708010. http://dx.doi.org/10.1186/1756-3305-4-120.

Rózsa LJ, Reiczigel J, Majoros G. Quantifying parasites in samples of hosts. J Parasitol 2000; 86(2): 228-232. PMid:10780537. http://dx.doi. org/10.1645/0022-3395(2000)086[0228:QPISOH]2.0.CO;2.

Santos GM, Mérona B, Juras AA, Jégu M. Peixes do baixo Rio Tocantins: 20 anos depois da Usina Hidrelética Tucuruí. Brasília: Eletronorte; 2004.

Silva AMO, Tavares-Dias M, Jerônimo GT, Martins ML. Parasite diversity in Oxydoras niger (Osteichthyes: Doradidae) from the basin of Solimóes River, Amazonas State, Brazil, and the relationship between monogenoidean and condition factor. Braz J Biol 2011; 71(3): 791-796 PMid:21881805. http://dx.doi.org/10.1590/S1519-69842011000400026.

Soares MGM, Costa EL, Siqueira-Souza F, Anjos HDB, Yamamoto KC, Freitas CEC. Peixes de lagos do médio Rio Solimóes. 2. ed. Manaus: Instituto Piatam; 2011

Tavares-Dias M, Dias-Júnior MBF, Florentino AC, Silva LMA, Cunha AC. Distribution pattern of crustacean ectoparasites of freshwater fish from Brazil. Rev Bras Parasitol Vet 2015; 24(2): 136-147. PMid:26154954. http://dx.doi.org/10.1590/S1984-29612015036

Tavares-Dias M, Oliveira MSB, Gonçalves RA, Neves LR. Parasitic diversity of a wild Satanoperca jurupari population, an ornamental cichlid in the Brazilian Amazon. Acta Amaz 2017; 47(2): 155-162. http://dx.doi org/10.1590/1809-4392201602514.

Vanhove MPM, Hablützel PI, Pariselle A, Šimková A, Huyse T, Raeymaekers JAM. Cichlids: a host of opportunities for evolutionary parasitology. Trends Parasitol 2016; 32(10): 820-832. PMid:27595383. http://dx.doi. org/10.1016/j.pt.2016.07.002

Vidal-Martínez VM, Pech D, Sures B, Purucker T, Poulin R. Can parasites really reveal environmental impact? Trends Parasitol 2010; 26(1): 44-51. PMid:19945346. http://dx.doi.org/10.1016/j.pt.2009.11.001.

Yamada FH, Takemoto RM, Bellay S, Pavanelli GC. Two new species of Sciadicleithrum (Monogenea, Dactylogyridae) parasites of Neotropical cichlid fishes from the Paraná River, Brazil. Acta Parasitol 2009; 54(1): 6-11. http://dx.doi.org/10.2478/s11686-009-0004-8.

Zar JH. Biostatistical analysis. 5. ed. New Jersey: Prentice Hall; 2010. 